\title{
BEHAVIOUR OF SILTY SAND REINFORCED WITH LOW DENSITY POLYETHYLENE (LDPE) STRIPS
}

Naveed Khan', Irshad Ahmad', Muhammad Safdar2,*, Abdul Qudoos Khan ${ }^{3}$ and Beenish Jehan Khan ${ }^{4}$

1. Department of Civil Engineering, University of Engineering and Technology, Peshawar, Pakistan

2. Earthquake Engineering Center, University of Engineering and Technology, Peshawar, Pakistan

3. Department of Civil Engineering, Military College of Engineering, Risalpur, Pakistan

4. Department of Civil Engineering, CECOS University, Peshawar, Pakistan

\section{ABSTRACT}

In this study, silty sand is reinforced with plastic strips to improve the engineering properties of soil. Sand and silty sand soils have been used as base materials and low-density polyethylene (LDPE) strips as reinforcement materials. The LDPE strips are used in various dimensions (e.g., width ranging from 6 to $15 \mathrm{~mm}$ and length ranging from 15 to $30 \mathrm{~mm}$ ). The randomly distributed LDPE strips are added to sand and silty sand specimens at varying percentages (e.g., $0.1 \%$ to $0.3 \%$ ) by weight of dry soil specimen. Direct shear tests are performed on sand and silty sand specimens in both unreinforced and reinforced conditions. Stress strain, volumetric strain (e.g., compression/dilation behaviour) and strength envelopes are plotted to investigate the improvement in the shear strength parameter (e.g., internal friction angle). The results show that in sand specimens, the maximum improvement in shearing behaviour has been achieved with strips of $6 \times 30 \mathrm{~mm}$ in dimensions and at $0.3 \%$. For silty sand specimens, the maximum improvement in shearing behaviour has been achieved with strips of $6 \times 25 \mathrm{~mm}$ in dimensions and at $0.3 \%$. In addition, it has been observed that reinforced soil specimens increased the values of internal frictional angle compared to unreinforced soil specimens. In sand specimens, maximum increase of $19.72 \%$ in internal friction angle $(\Phi)$ has been observed with $6 \times 30 \mathrm{~mm}$ strips at similar percentage. In case of silty sand specimens, the maximum increase in internal friction angle (Ф) has been observed as $19.28 \%$ with the addition of strips of $6 \times 25 \mathrm{~mm}$ and at $0.3 \%$.

KEYWORDS: Soil reinforcement, silty sand, LDPE strips, direct shear test, internal friction angle, dilation

*Corresponding author: (Email: drsafdar@uetpeshawar.edu.pk)

\section{INTRODUCTION}

Soil reinforcement is an ancient technique used to improve the engineering properties of soil. It has shown a major contribution in geotechnical engineering applications. Civil engineering structures (e.g., buildings, roads, bridges, dams, tunnels etc.) rest on soil and transfer their load to the soil through foundation. If the underneath soil is soft, then structure failure may take place due to compressibility, differential settlement or shear failure of soil. In such cases, the ground condition and soil properties are not suitable for the proposed structure. In situations like this, geotechnical engineers need to address the potential problems with viable solution. Soil reinforcement or stabilization of soil can be considered as an effective technique to achieve the desired objectives. Depending upon the available soil characteristic, ground condition and desired objectives, the soil improvement technique and materials may be selected to solve the challenges. In addition, such ground improvement techniques are utilized to make the site suitable for construction at reasonable cost 
[1].

The engineering properties of the soil may be improved with the inclusion of reinforcing elements into the soil. The term soil includes sand, silt, clay and gravel of any sizes produced from rock by the process of weathering. And, reinforcement means the natural or synthetic materials capable to withstand the tensile stresses. There are many methods available to reinforce the soil, and different materials may be used for reinforcing soils (e.g., low tensile strength gross roots to high tensile strength steel strips). These reinforcement materials may be added to soil in different shapes such as in the form of fibres, strips, grids, sheets, bars [2, 3, 43, 5]. With the inclusion of such reinforcing elements, the engineering properties of the soil are improved such as density, shear strength, compressibility, and permeability [6], rigidity and tensile strength [7], ductility and material strength [8]. The reinforcement technique has been significantly used in road construction, stabilization of subgrade materials, slope stability analysis, embankment, and earth retaining structures [3].

In soil reinforcement, tensile strength materials have been used in various size and shapes. These elements have different tensile strength ranging from low modular strength fibres to high tensile strength steel strips. In ancient time some natural materials of low tensile strength such as plant roots, straws, jute, sisal and bamboo were added to soil for reinforcement purposes. However, the modern concepts of soil reinforcement were introduced in early 1960s by Henri Vidal. High tensile strength galvanized steel strips were used as reinforcement element in construction of mechanically stabilized earth (MSE) retaining walls to provide resistance against lateral earth pressure [9]. And since 1970s, numerous research studies with regard to soil reinforcement with different external materials have been undertaken by various researcher. Different types of materials such as highdensity polyethylene (HDPE), polypropylene (PP), carpet fibre, recycled rubber tire shred etc. $[3,10,11,12,13,14]$ have been reported in the literature to increase the shear strength of soils.

In this research study directs shear tests were performed on sand in pure and reinforced condition (fibres and wires) [3]. Analysis of test results revealed an increase in shear resistance in direct proportion with fibres oriented at $60^{\circ}$ to shear surface. Gray [2] conducted research study to analyse the shear behaviour of sand. In this research study, sand was reinforced with woven (fabricated) and nonwoven (natural) fibres. A series of triaxial compression tests were performed. Results showed an improvement in shear strength and axial strain and loss in post peak shear strength was reduced. Maher [7] studied the stress-strain behaviour of sand reinforced with discrete and randomly distributed fibres. A set of triaxial compression tests were carried out and enhancement in shear strength were observed. Reclaimed high-density polyethylene (HDPE) strips were used as reinforcement materials [10] with sand and carried out direct shear, resilient modulus and California Bearing Ratio (CBR) tests to investigate the shear strength and resistance to deformation behaviour of sand. Tests results revealed that reinforcing sand with reclaimed HDPE strips increase both the shear strength and resistance to deformation.

Consoli [4] used pure sand and sand been stabilized with cement and plastic waste. Unconfined compression tests, splitting tests 
and triaxial compression tests were performed to analyse the engineering behaviour of both cemented and uncemented soil in pure and reinforced conditions with plastic waste. Results revealed an improvement in shear strength and decrease in brittleness of cemented sand when reinforced with plastic fibres. Santoni et al., [15] performed research on different types of sand specimens reinforced with different types of discrete fibres at varying fibre contents. Laboratory based unconfined compression tests reported a significant improvement in unconfined compressive strength of sand specimens at optimum fibre content between 0.6 to $1.0 \%$ by weight of dry sand. In addition, it was reported that the improvement was not affected by addition of up to $8.0 \%$ of silt content. Analysis based on direct shear test results further revealed an improvement in shear strength of sandy soils reinforced with high-density polyethylene. Sand been reinforced with randomly distributed high-density polyethylene (HDPE) strips of various dimensions and concentration and tested in direct shear conditions. Results reported increases in the peak friction angle [12].

Murray et al., [16] performed laboratory compaction and triaxial compression tests on sandy silt reinforced with randomly distributed carpet and polypropylene fibres. Laboratory compaction test results showed a decrease in maximum dry density with increasing fibres content; however, triaxial compression test results revealed improvement in shear strength of sandy silt with both type and fibre content. Zornberg [17] investigated the behaviour of fibre-reinforced sand, analysed the data from previous research and also developed a frame work for future research to study the behaviour of fibre-reinforced soils.
Michalowski [18] performed a set of drained triaxial compression tests on sand specimens reinforced with synthetic fibres. Test results showed that a fall in initial stiffness and improvement in failure displacement with fibre addition. With concentration of fibres by volume of up to $2.0 \%$, improvement in failure stress may be as much as $70.0 \%$. In addition, it was reported that grain size of sand specimen and aspect ratio of fibres are also important in increasing the strength of soils. Zornberg et al., [11] carried out experimental study using large-scale triaxial testing to evaluate the optimum dosage and aspect ratio of recycled tires shred with sand fills. Results revealed that tire shred content and aspect ratio remarkably influence the stress-strain and volumetric strain behaviour of the composite material. The maximum strength was achieved by adding up to $35.0 \%$ of tire shred.

Heineck et al., [19] investigated the behaviour of fibre reinforced soil ranging from very small shear displacements to very large shear displacements. Sand, silty sand, bottom ash and polypropylene fibres were used and ring shear and triaxial compression tests were performed. Results showed that even at very large shear displacement, there is no loss in shear strength due to fibre-reinforcement, though it has a significant influence on the ultimate strength. Ibrahim [20] conducted a study comprised of performing compaction and direct shear tests on very fine sand reinforced with randomly oriented polypropylene fibres. Results reported that reinforcement caused a less dense composite packing and direct shear test results indicated that fibres inclusions caused an improvement in peak shear strength. Reports of triaxial compression tests carried out by Consoli [8] described the effects of cement and fibre 
inclusions on stress-dilatancy behaviour of sand. Stiffness, peak strength and brittleness of sand increased with the addition of cement. However, fibre inclusions increased the ultimate strength and ductility and decreased the stiffness of cemented sand specimens. Results of extensive laboratory based on direct shear testing program using different types of sands reinforced with different types of fibres indicated that addition of fibres having aspect ratio from 40 to 150 and 0.5 to $1.50 \%$ increased the shear strength and ductility of sand-fibre composite. The maximum increase in shear strength of $37 \%$ was obtained with fibre content ratio of $1.0 \%$ and aspect ratio of 150. The fibre-reinforcement also paired with increase in tendency for dilation, the increase in dilation/vertical displacement being more apparent for coarse sand than fine sand [21]. A comprehensive research study carried out by Sadek et al., [21] showed that the shear strength (peak and residual) of fibrereinforced sands was significantly dependent on sand fineness, fibre concentration and density state of composite. It was observed that in case of sandy silt soil, the peak shear stress increased up to $59 \%$ with the inclusion of fibre up to $0.5 \%$, while in case of silty clay soils, the peak shear stress increased up to $24 \%$ with the inclusion of fibre up to $0.9 \%$. Eldesouky et al., [22] carried out an investigation to evaluate the influence of fibres on shear strength and volumetric behaviour of sand. A series of direct shear tests were performed, results revealed an increase in shear strength and dilation of sand due to fibre inclusions. llieş [14] conducted a research study on the application of reusing plastic waste in soil stabilization. The study was based on comparing the improvement of soil mechanical parameters due to plastic waste and cement. Results reported that the plastic waste for soil stabilization can be considered an eco-friendly and sustainable method. A series of triaxial compression tests and fibre pullout tests were carried out to assess how tension mobilized in fibres under varying shear strain levels. Analysis of results showed that full mobilization of tension in fibres took place at higher strain levels [23]. Fibre content and dimensions had a remarkable effect on shear strength and stress-strain behaviour of sand. Results revealed an improvement in internal friction angles of sand been reinforced with polypropylene meshed and smooth fibres. However, sand reinforced with meshed fibres resulted more increases compared to smooth fibres [13]. In addition, Gray [3] presented theoretical equations based on force equilibrium principles for modeling the enhancement in shear strength of soil due to fibre inclusions. Other researchers used discrete formulation [11] and energy dissipation formulation [18] to model shear strength increase due fibre additives.

Experimental study revealed that addition of silt content significantly affects the shear strength behaviour [24] of pure sand. It was reported that addition of fines influences the void ratio and density of soils. In addition, results further reported that up to $25 \%$ of silt content significantly affected the strength characteristics of composite materials. However, limited studies have been reported on the use of LDPE in improving the strength and volumetric behaviour of silty sands. In this study, silty sand is reinforced with plastic strips to improve the engineering properties of soil. Sand and silty sand soils are used as base materials and low-density polyethylene (LDPE) strips as reinforcement materials. Direct shear tests are performed on sand and silty sand 
specimens in both unreinforced and reinforced conditions. Stress strain, volumetric strain (e.g., compression/dilation behaviour) and strength envelopes are plotted to investigate the improvement in the shear strength parameter (e.g., internal friction angle).

\section{TESTED MATERIALS AND METHODS}

Research materials used in testing program of the current research study are composed of sand, silty-sand and low-density polyethylene (LDPE) strips. In this research study, sand and silty sand soil were used as base materials and lowdensity polyethylene (LDPE) strips as reinforcement materials. According to standard practice for classification of soils for engineering purposes (Unified Soil Classification System-USCS), sand-soil composed of rock particles which will pass No. 4 (4.75 mm) sieve and will retain on a No. 200 (75 $\mu \mathrm{m})$ U.S standard sieve, and, silt-soil composed of particles that will pass a No. 200 (75 $\mu \mathrm{m})$ U.S standard sieve. In this research program, the soil samples were collected for preparation of the desired soil specimens from Nori-Abad site located near Karachi, Pakistan.

According to the USCS, the desired sand sample was obtained through sieve analysis [25]. Sand samples were composed of particles passing a No. $4(4.75 \mathrm{~mm})$ sieve and retained on

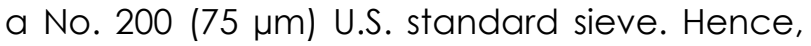
particles of sand sample ranging in size from $0.075 \mathrm{~mm}$ to $4.75 \mathrm{~mm}$. Pure sand and sandLDPE composite have been shown in Figure.1 and Figure.2 respectively.

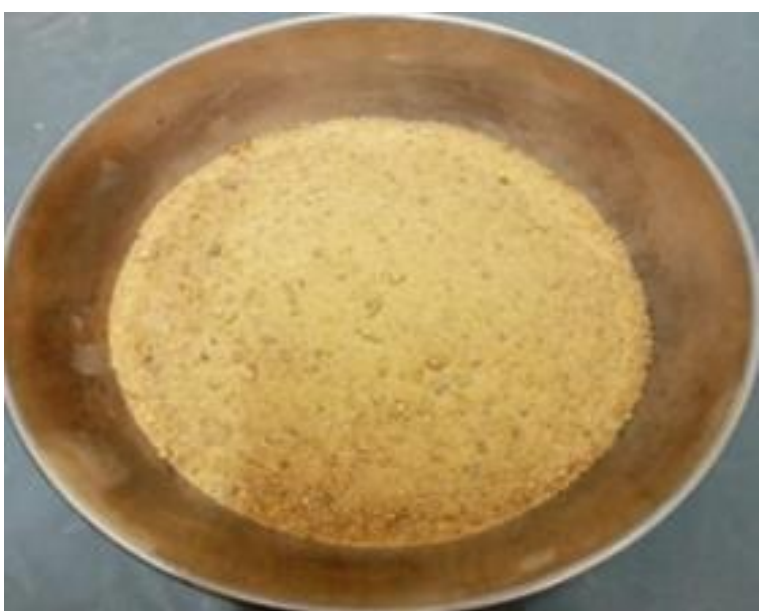

Figure.1. Pure sand

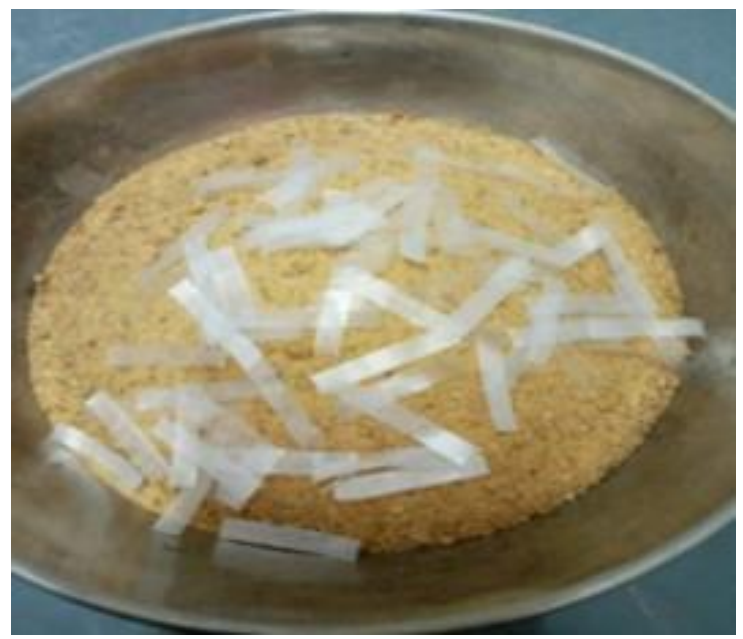

Figure.2. Sand-LDPE composite

Similarly, the silty sand sample was obtained through sieve analysis. Silty sand sample was composed of $80 \%$ sand and $20 \%$ silt. According to USCS, silt-soil comprising of particles passing

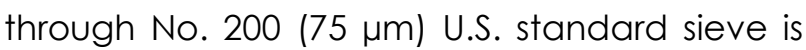
used. Silty sand and Silty sand-LDPE composite have been shown in Figure.3 and Figure.4 respectively. 


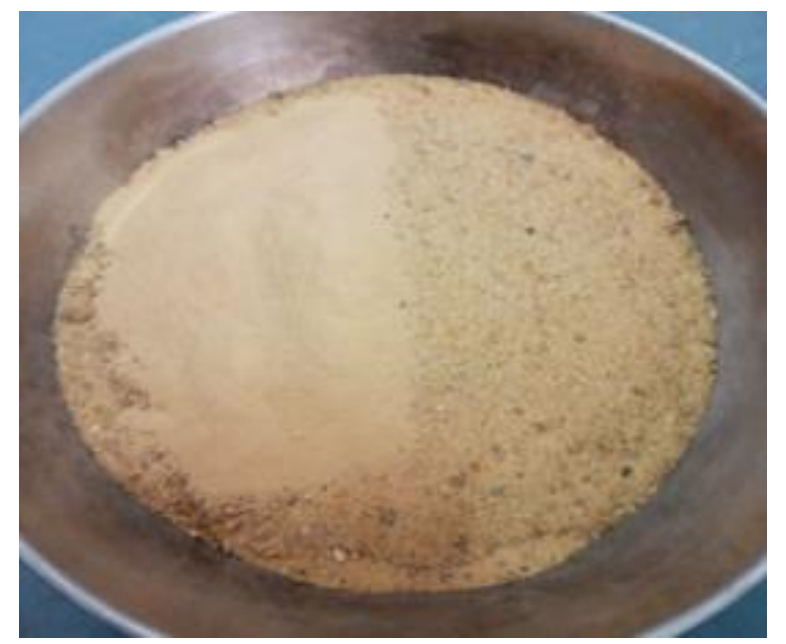

Figure.3. Silty Sand

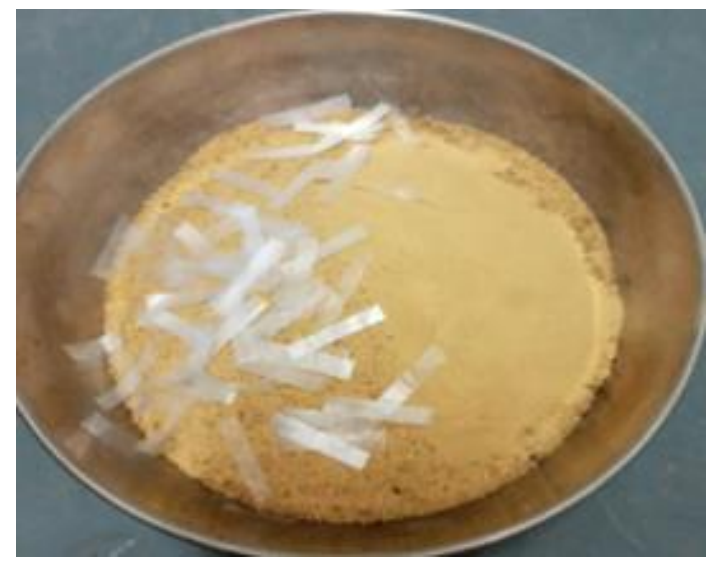

Figure.4. Silty sand - LDPE composite

In this research study, low-density polyethylene (LDPE) plastic bags strips have been used as reinforcement materials. For this purpose, LDPE plastic bags were obtained from a commercial market in Karachi. From these LDPE plastic bags, strips of desired dimensions such as $6 \times 15 \mathrm{~mm}, 6 \times 25 \mathrm{~mm}, 6 \times 30 \mathrm{~mm}, 12 \times$ $15 \mathrm{~mm}$ and $18 \times 15 \mathrm{~mm}$ were prepared. Further, these strips were added to soil as reinforcement materials at concentration of $0.1 \%, 0.2 \%$ and $0.3 \%$ by weight of dry soil specimen. LDPE strips of dimensions $6 \times 25 \mathrm{~mm}$ and $6 \times 30 \mathrm{~mm}$, are shown in Figure. 5 and Figure. 6, respectively. Properties of LDPE are presented in Table 1.
Table:1 Characteristics of Low-Density Polyethylene (CETIN M, 2013)

\begin{tabular}{|l|c|}
\hline Density & $\begin{array}{c}910-928 \mathrm{Kg} / \mathrm{m}^{3}(0.910-0.928 \\
\left.\mathrm{g} / \mathrm{cm}^{3}\right)\end{array}$ \\
\hline Melting Point & $120^{\circ} \mathrm{C}\left(248^{\circ} \mathrm{F}\right)$ \\
\hline Melting Temperature & $125-136^{\circ} \mathrm{C}\left(257-277^{\circ} \mathrm{F}\right)$ \\
\hline Maximum & $80^{\circ} \mathrm{C}\left(176^{\circ} \mathrm{F}\right)$ \\
\hline Temperature & $50^{\circ} \mathrm{C}\left(58^{\circ} \mathrm{F}\right)$ \\
\hline Minimum & \\
\hline Temperature & $150-200 \mathrm{e}-6 / \mathrm{K}$ \\
\hline Thermal Expansion & $8-12 \mathrm{MPa}$ \\
\hline Tensile Strength & $200-400 \mathrm{MPa}$ \\
\hline Young Modulus (E) & $100-350 \mathrm{MPa}$ \\
\hline Shear Modulus & \\
\hline
\end{tabular}

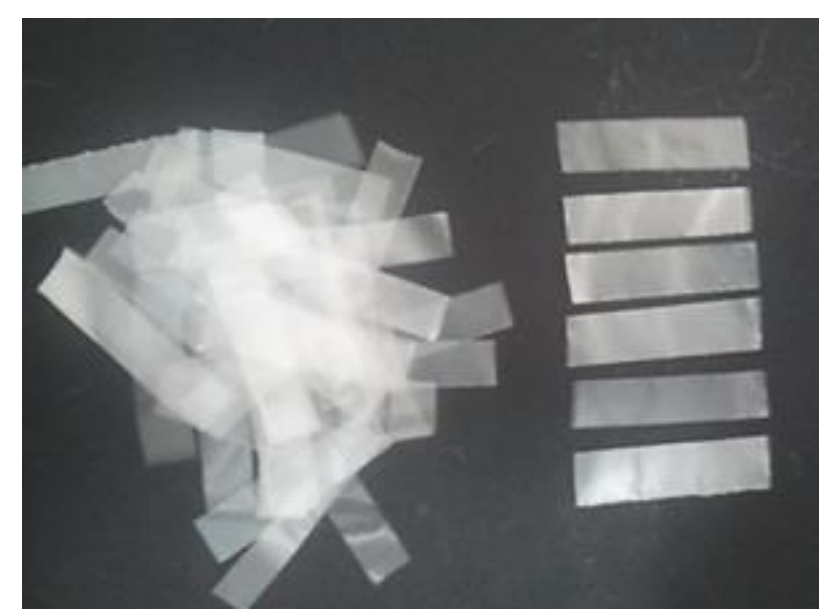

Figure.5. LDPE Strips $6 \times 25 \mathrm{~mm}$

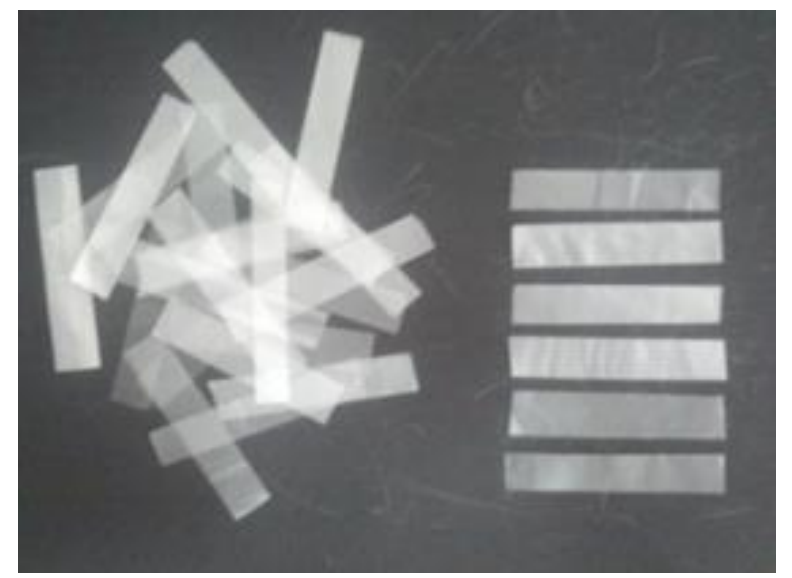

Figure.6. LDPE Strips $6 \times 30 \mathrm{~mm}$ 


\subsection{Sieve Analysis - Particle Size Distribution Curve}

Sieve analysis consists of shaking soil sample in a set of sieves arranged in such a way that larger opening sieves are placed at the top followed by progressively smaller opening sieves and a pan is placed below the stack. To perform sieve analysis of soil, one has to use oven dry soil [26]. According to ASTM C136 [27], first dry the sample to constant mass at a temperature of $110 \pm 50 C$. Select sieves with suitable openings to obtain the information required for covering the material to be tested. Arrange the sieves in order of decreasing size of opening from top to bottom and place the sample on the top sieve. The soil is then shaken for a sufficient period of time. After the soil is shaken, the necessary steps such as the mass of sand retained on each sieve, total mass, cumulative mass and percent finer are determined. These calculations are plotted on semi-logarithmic graph with percent finer as ordinate on arithmetic scale and sieve opening size as abscissa on logarithmic scale. The plot or graph so obtained is referred to particle/grain size distribution (GSD) curve. Grain size distribution curves of sand and silty sand soils are shown in Figure. 7 and Figure. 8, respectively. The grain size distribution curves can be used for the determination of parameters such as effective and mean diameters D10, D30, D50, D60, coefficient of uniformity (Cu) and coefficient of curvature (Cc). The granulometric characteristics of both sand and silty sand soils are presented in Table 2.

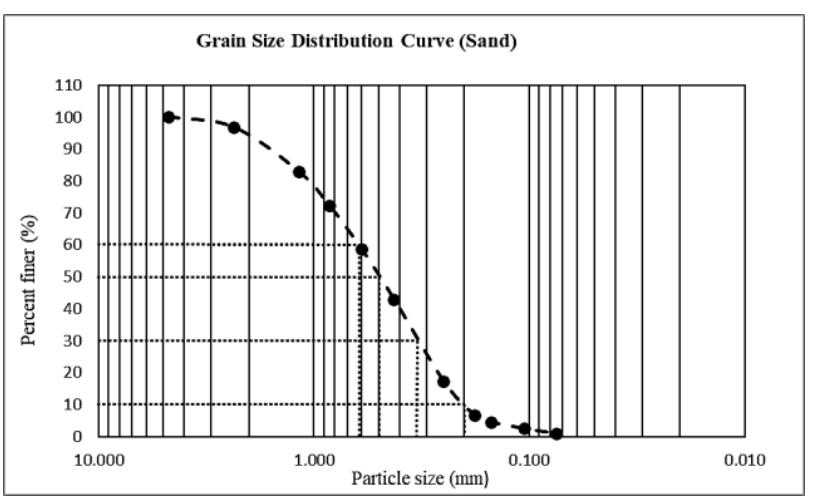

Figure.7. Particle size distribution curve of sand

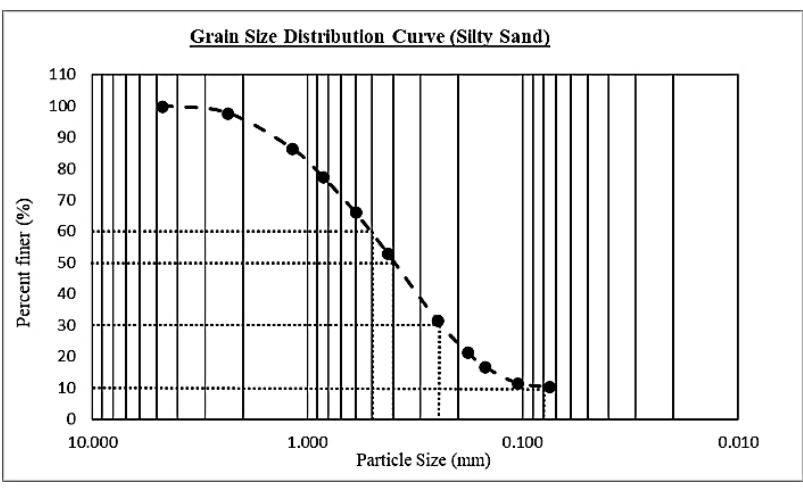

Figure.8. Particle size distribution curve of silty sand

Table:2 Properties of sand and silty sand soil from particle size distributions.

\begin{tabular}{|l|l|l|l|l|l|l|}
\hline Description & $\begin{array}{l}\mathbf{D}_{\mathbf{1 0}} \\
\mathbf{( m m )}\end{array}$ & $\begin{array}{l}\mathbf{D}_{\mathbf{3 0}} \\
\mathbf{( m m )}\end{array}$ & $\begin{array}{l}\mathbf{D}_{50} \\
\mathbf{( m m )}\end{array}$ & $\begin{array}{l}\mathbf{D}_{\mathbf{6 0}} \\
\mathbf{( m m )}\end{array}$ & $\mathbf{C c}$ & $\mathbf{C u}$ \\
\hline Sand & 0.206 & 0.335 & 0.500 & 0.618 & 0.882 & 3.00 \\
\hline Silty Sand & 0.080 & 0.251 & 0.400 & 0.500 & 1.58 & 6.25 \\
\hline
\end{tabular}

In this study, direct shear machine has been used. It consists of shear box (60 x $60 \times 30 \mathrm{~mm})$, splits horizontally into two halves. Soil specimen is accommodated inside and subjected to horizontal shearing. Shear loading device having dynamometric ring is used to exert shearing load on soil specimen in horizontal direction. This horizontal shear loading is measured by a dial gauge fixed inside the dynamometric ring. Normal/vertical loading system-through which normal load is applied on soil specimen. The normal loading system consists of a horizontal loading frame where a 
loading hanger is attached. Dead weights are placed in the hanger and the required normal load is applied on soil specimen. Touch screen display contains multifunction display options, which are used to set out machine for operating purposes. Three dial gauges are used to measure vertical deformation, horizontal displacement and horizontal shear loading.

Testing program of this study was comprised of performing a set of small direct shear tests on reinforced and unreinforced soils under different normal loading conditions. The soil samples were dried in oven at 110 o $\mathrm{C}$ for 24 hours to eliminate moisture effect and obtain a homogenous soil-strips composite. According to [28], sand and silty-sand specimens were prepared for testing. Two porous stone were placed, one below and one above the soil specimen to facilitate the drainage of pore water from the specimen. Before testing, each specimen was consolidated under the corresponding normal load and then subjected to shear testing in direct shear apparatus. During testing, the vertical deformation, horizontal deformation and shearing load were carefully recorded. In the first phase, direct shear tests were performed on sand specimens in pure/unreinforced conditions under different normal loading conditions, and parameters like compression/dilation behaviour, shear stress behaviour and Mohr-coulomb envelopes of the soil were considered. In second phase, LDPE strips of different dimensions were added to sand specimens at different concentrations. Reinforced specimens were prepared, consolidated under the corresponding normal loading conditions, then subjected to shear testing in direct shear machine, and same parameters were considered. The maximum increase in shearing behaviour of sand specimens was observed with strips $6 \times 30 \mathrm{~mm}$ and at concentration of $0.3 \%$ of the weight of the dry specimen. Similar procedure was adopted for silty sand specimens as well. However, the maximum increase in shearing behaviour of silty sand was observed with strips $6 \times 25 \mathrm{~mm}$ and at concentration of $0.3 \%$ of the weight of the dry specimen.

\section{RESULTS AND DISCUSSIONS}

In this study, following parameters of direct shear tests are considered for sand and silty sand in both pure/unreinforced and reinforced conditions.

- Compression/dilation vs shear strain graphs (Compression/dilation behaviour of soil)

- Shear stress vs shear strain graphs (Stressstrain behaviour of soil)

- Shear stress vs Normal stress graphs (MohrCoulomb envelops)

For the determination of compression/ dilation behaviour of sand in pure/unreinforced conditions, the unreinforced specimens were subjected to shearing under different normal loading conditions and the corresponding graphs were plotted below (see Figure.9). And for investigating the influence of LDPE strips on compression/dilation behaviour of sand, the reinforced sand specimen was subjected to shearing in similar manner and the corresponding graphs were obtained. Graphs of reinforced and unreinforced sand specimen have been compared with each other, showing that reinforced sand specimens show more dilative behaviour compared to unreinforced specimens under same normal stress. 


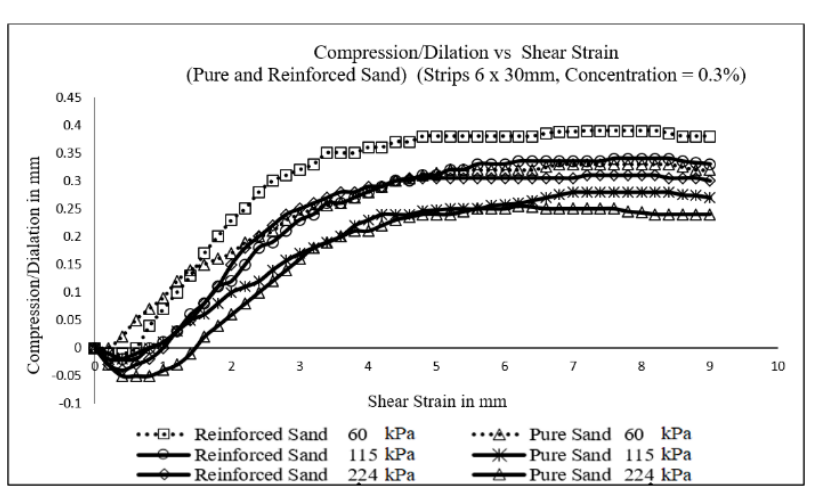

Figure.9. Comparison of compression/dilation vs shear strain behaviour of pure and reinforced sand.

Similar procedure was also adopted for analyzing the compression/dilation behaviour of silty sand soils. Comparison of compression/dilation behaviours of silty sand soils in reinforced and unreinforced conditions has been presented in Figure. 10.

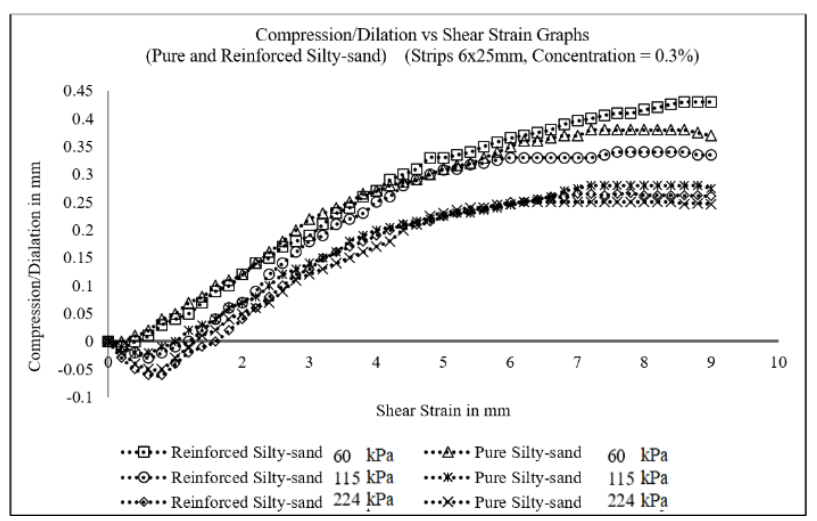

Figure.10. Comparison of compression/dilation vs shear strain behaviour of pure and reinforced silty sand

For determining the compression/dilation behaviour of sand and silty sand soil in pure/unreinforced conditions, representative specimens of the sand and silty sand soils in pure conditions were subjected to shearing tests under different normal loading conditions in direct shear machine and their compression/dilation behaviours were observed. Similarly, for determining the compression/dilation behaviour of reinforced sand and silty-sand soils, representative specimen of soil in reinforced conditions were subjected to shearing tests and their compression dilation behaviours were observed. As stated, before that sand samples were composed of particles ranging in size from 0.075 to 4.75 millimetres, and silty-sand samples were composed of $80 \%$ sand and $20 \%$ silt (e.g. silt particles having size less than $0.075 \mathrm{~mm}$ ). Due to difference in their particle sizes the rate of dilation of sand specimen is quite different than silty-sand specimen. During shearing, soil particles roll over each other which results dilation, in case of sand specimen there is no fines content, so during shearing the coarse sand particles have a direct collision and rolling over each other which results dilation with high rate up to failure stress, however in case of silty sand specimen there exists $20 \%$ fines content which cover up the empty spaces among the coarse particles up to some percentage, so during shearing the coarse particles does not undertake direct collisions and rolling with coarse particles as the fines particles intervene coarse particles and results dilation with a comparatively gradual rate. Comparison of compression/dilation graphs of sand and silty sand soil in pure/unreinforced and reinforced conditions under same normal stress of $60 \mathrm{KPa}$ have been presented in Figure. 11 and Figure. 12 , respectively.

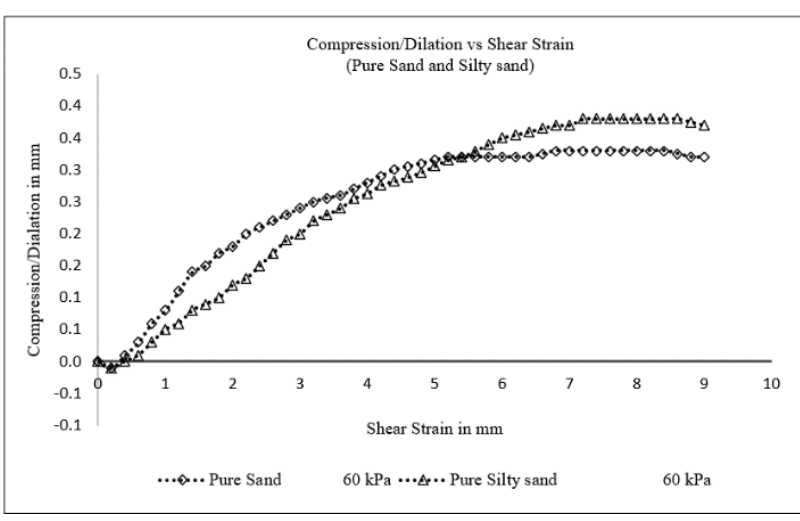

Figure.11. Comparison of compression/dilation vs shear strain graphs of pure sand and pure silty sand 


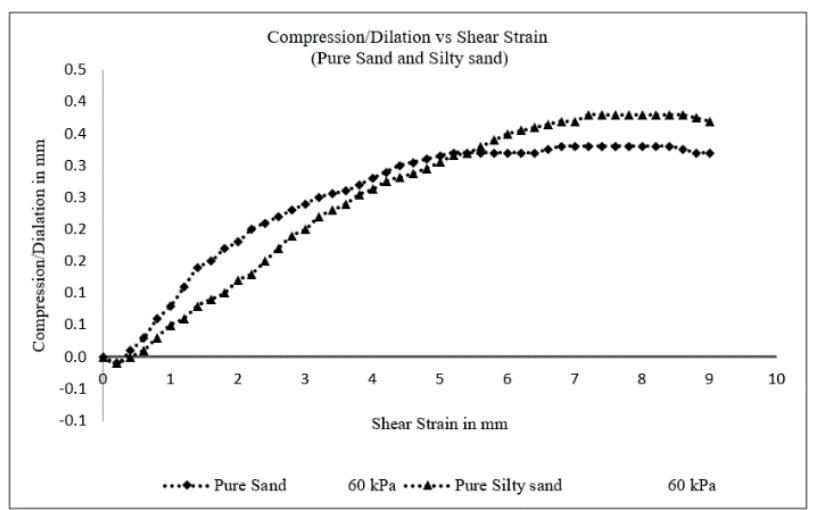

Figure.12. Comparison of compression/dilation vs shear strain behaviour of reinforced sand and reinforced silty sand

The influence of plastic strips parameters such as dimensions and concentrations on soil shear resistance under different applied normal stresses based on peak shear stresses was analysed for each specimen. Sand and siltysand specimens both in pure and reinforced conditions were subjected to shearing tests in direct shear machine, in each specimen it was observed that under each normal stress the shear stress behaviour increases with high rate up to failure stress (so called peak shear strength), when the failure stress is attained then it decreases with gradual rate until it reaches a constant value which is called ultimate shear strength. However, reinforced specimens of both sand and silty sand soils resulted more shear stress values than unreinforced specimens. Comparison of shear stress behaviours of reinforced and unreinforced specimens of sand and silty sand soils are presented in Figure. 13 and Figure. 14, respectively.

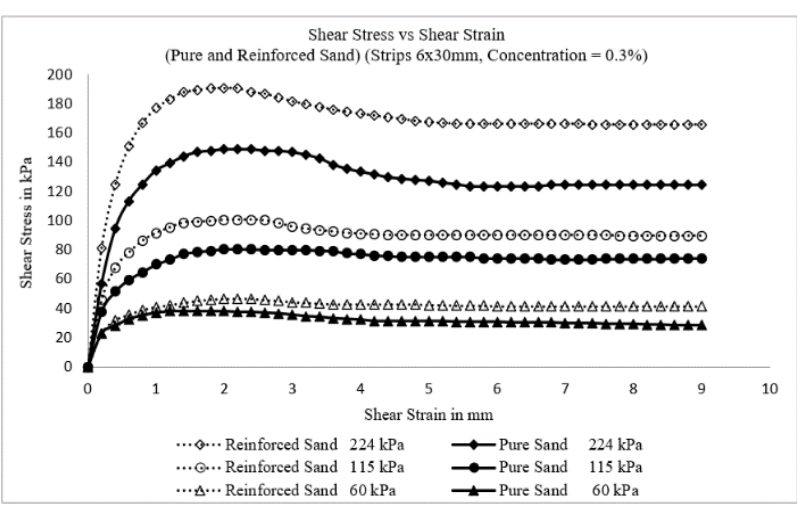

Figure.13. Comparison of shear stress vs shear strain behaviour of pure and reinforced sand

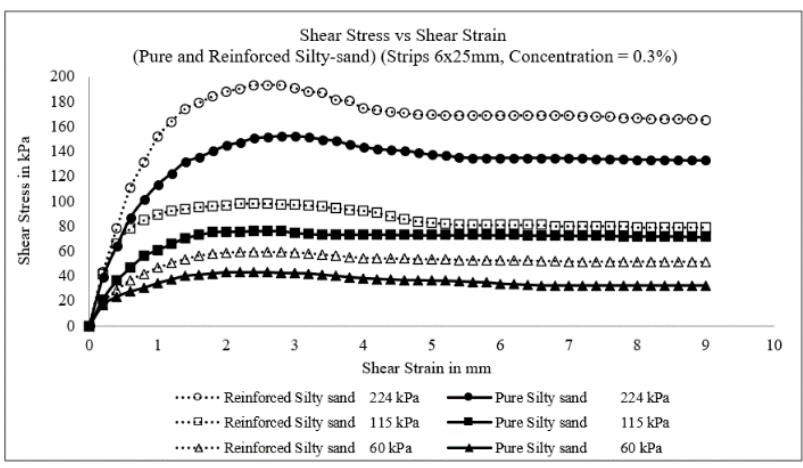

Figure.14. Comparison of shear stress vs shear strain behaviour of pure and reinforced silty sand

For determining the shear stress behaviour of sand and silty-sand soil in pure conditions, representative specimen of sand and silty-sand soil in pure conditions were subjected to shearing tests under different normal loading conditions and the corresponding shear stress behaviour were observed. To investigate the influence of plastic strips parameters like strips size and concentrations on shear stress behaviour of sand and silty-sand soils, the representative specimen of sand and silty-sand soil in reinforced conditions were also subjected to shearing tests and their shear stress behaviour were observed (see, Table 3). As mentioned in previous paragraph that during shearing, in both reinforced and unreinforced soil specimen the shear stress values increases with shear strain, initially with high rate up to failure stress 
(which is called peak shear strength), once the failure stress is attained, the shear stress starts decreasing with gradual rate until it reaches a constant value which is called ultimate shear strength. However, in both sand and silty-sand specimens, reinforced specimens resulted greater shear stress values than unreinforced specimens (see, Table 4). As mentioned before that sand sample and silty-sand sample have difference in their particle sizes, due to which, rate of shear stress of sand specimen is quite different than that of silty-sand specimen in both reinforced and unreinforced conditions. Rate of shear stress in sand specimen is comparatively high than silty-sand specimen in both reinforced and unreinforced conditions, so sand specimen attain its peak shear stress value at comparatively shorter shear strain than siltysand specimen as shown in figures given below. Comparison of shear stress behaviour of sand and silty-sand specimen in pure and reinforced conditions have been presented in Figure. 15 and Figure. 16, respectively.

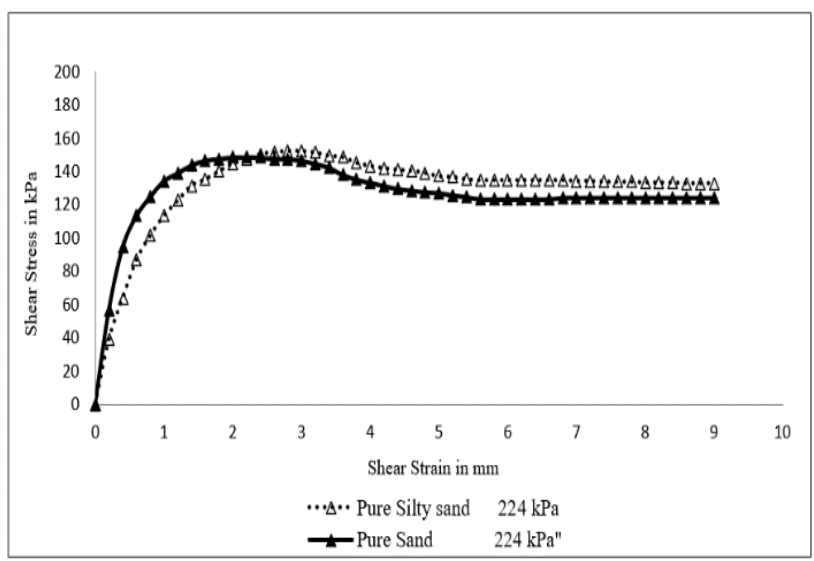

Figure.15. Comparison of shear stress vs shear strain of pure sand and pure silty sand

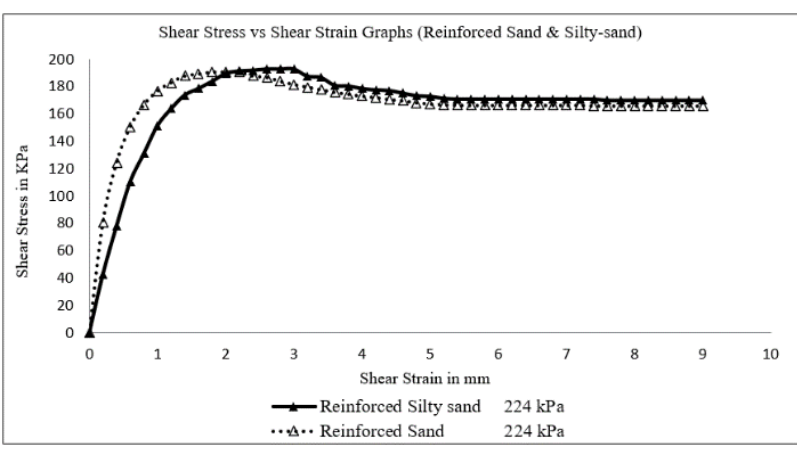

Figure.16. Comparison of shear stress vs shear strain of reinforced sand and reinforced silty sand

Internal friction angles of sand and silty-sand specimens in reinforced and unreinforced conditions have been determined from the peak shear stress values at three different applied normal stresses. Tests on sand and siltysand specimen in pure/unreinforced conditions resulted friction angles of $33.86^{\circ}$ and $34.188^{\circ}$ respectively. And, reinforced soil specimen resulted in various values of friction angle depends upon the parameters of LDPE strips such as width, length and concentration. Graphs of friction angle of sand and silty sands in reinforced and unreinforced conditions determined from experimental results are shown in Figure. 17 and Figure. 18 respectively. The impact on the friction angle of sand and siltysand soil due to plastic strips inclusions has been examined to establish a relation with influence of plastic material on the friction angle of sand and silty-sand soil. Analysis of the results revealed an enhancement in the peak friction angle of sand and silty-sand soils with inclusions of plastic strips when compared with peak friction angle of sand and silty-sand soil having no strips inclusions. However, the maximum increase in friction angle of sand was found from $33.86^{\circ}$ to $40.54^{\circ}$ with strips inclusions of width - 6 $\mathrm{mm}$, length $-30 \mathrm{~mm}$ and at concentration of 0.3 $\%$ by weight, resulted in a percentage improvement of $19.72 \%$. Similarly, the maximum increase in friction angle of silty-sand was found 
from $34.188^{\circ}$ to $40.78^{\circ}$, which was achieved with strips inclusions of width $-6 \mathrm{~mm}$, length - $25 \mathrm{~mm}$ and at concentration of $0.3 \%$ by weight, which caused a percentage improvement of $19.28 \%$. It can be seen that the percentage enhancement in internal friction angle of sand specimen is more than silty sand specimen. This type influence has also found in research studies conducted in past. As, in this study direct shear test has been used as indicator test, during shear loading the stresses developed in soil-strips composite leads to mobilization of tensile strength of plastic strips which absorb the shear stresses exceeding the pure/unreinforced soil capacity.

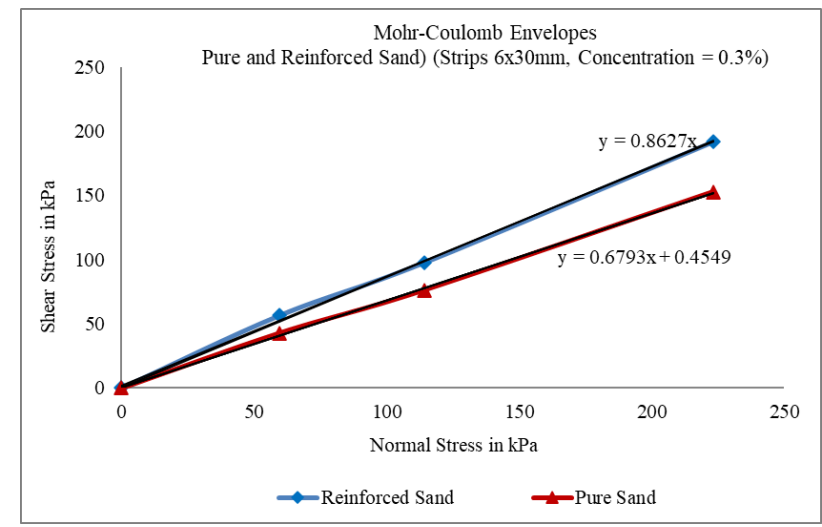

Figure.17. Mohr-Coulomb envelops of pure and reinforced sand. Pure Sand $(\Phi)=33.86^{\circ}$ Reinforced Sand $(\Phi)=40.54$ Increase $(\Phi)=19.72 \%$

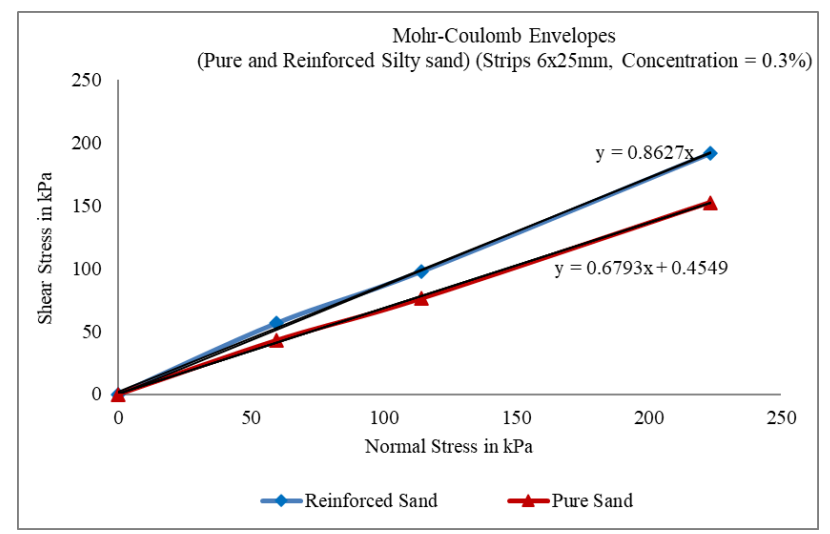

Figure.18. Mohr-Coulomb envelops of pure and Reinforced silty sand

Pure Silty-sand $(\Phi)=34.188^{\circ}$

Reinforced Silty-sand $(\Phi)=40.78^{\circ}$

Increase $(\Phi)=19.28 \%$

Table:3 Percent addition of strips by weight as well as corresponding size of striP

\begin{tabular}{|c|c|c|c|c|}
\hline Description & $\begin{array}{c}\text { Unreinforced } \\
\text { Sand }\end{array}$ & $\begin{array}{c}\text { Reinforced } \\
\text { sand }\end{array}$ & $\begin{array}{c}\text { Unreinforced } \\
\text { Silty sand }\end{array}$ & $\begin{array}{c}\text { Reinforced } \\
\text { Silty sand }\end{array}$ \\
\hline Size of Strips used & - & $6 \mathrm{~mm} \times 30 \mathrm{~mm}$ & - & $6 \mathrm{~mm} \times 25 \mathrm{~mm}$ \\
\hline $\begin{array}{c}\text { Addition by } \\
\text { weight }\end{array}$ & - & $0.3 \%$ & - & $0.3 \%$ \\
\hline
\end{tabular}


Table:4 Tabulated values of all results

\begin{tabular}{|c|c|c|c|c|c|}
\hline $\begin{array}{l}\text { Normal Stress } \\
\qquad(\mathrm{kPa})\end{array}$ & Description & $\begin{array}{l}\text { Unreinforced } \\
\text { Sand }\end{array}$ & $\begin{array}{l}\text { Reinforced } \\
\text { Sand }\end{array}$ & $\begin{array}{l}\text { Unreinforced } \\
\text { Silty sand }\end{array}$ & $\begin{array}{l}\text { Reinforced } \\
\text { Silty sand }\end{array}$ \\
\hline 60 & \multirow{3}{*}{$\begin{array}{c}\text { Compression/Dilatio } \\
n n(\mathrm{~mm})\end{array}$} & 0.31 & 0.39 & 0.38 & 0.43 \\
\hline 115 & & 0.28 & 0.34 & 0.28 & 0.34 \\
\hline 225 & & 0.25 & 0.31 & 0.25 & 0.263 \\
\hline 60 & \multirow{3}{*}{$\begin{array}{c}\text { Shear Stresses } \\
\text { (kPa) }\end{array}$} & 38.13 & 46.72 & 42.90 & 59.11 \\
\hline 115 & & 80.56 & 100.6 & 76.27 & 97.72 \\
\hline 225 & & 148.74 & 190.70 & 152.55 & 193.075 \\
\hline \multicolumn{2}{|c|}{$\begin{array}{l}\text { Angle of Internal Friction } \\
\text { (Degree) }\end{array}$} & 33.86 & 40.54 & 34.188 & 40.78 \\
\hline
\end{tabular}

\section{CONCLUSIONS}

In this study, a series of small direct shear tests are carried out under different normal loading conditions on pure/unreinforced sand and siltysand specimens. Then, discrete randomly oriented LDPE strips of different dimensions were added to the soils at various concentrations. The objectives of the current research study are to examine the influence of LDPE strips on compression/dilation behaviour, shear stress behaviour and internal friction angle of sand and silty-sand soils.

Based on the data and results obtained in this study, the following conclusions can be drawn;

- It has been observed that reinforced specimen of both sand and silty-sand soil exhibits greater dilation than unreinforced specimens. In case of sand, $25.80 \%$ increase has been observed under applied the load of $60 \mathrm{kPa}$ by adding LDPE strips. For silty sand, $13.16 \%$ increase has been observed by inclusion of LDPE strips.

- It has been observed that reinforced specimens of both sand and silty sand soil undertake greater shear stress values than pure/unreinforced specimens. For sand, $28.21 \%$ increase has been observed under the normal load of $224 \mathrm{kPa}$ and for silty sand, the increase is $26.56 \%$.

- In sand specimens, maximum improvement in friction angle is observed as $19.72 \%$ with LDPE strips inclusions having dimensions of 6 $x 30 \mathrm{~mm}$ and at concentration of $0.3 \%$ by weight of dry soil specimen.

- In silty sand specimens, maximum improvement in friction angle is observed up to $19.28 \%$ with LDPE strips inclusions having dimensions of $6 \times 25 \mathrm{~mm}$ and at concentration of $0.3 \%$ by the weight of dry soil specimen.

- Research finding of this study favourably suggest the application of LDPE as reinforcing materials for improving shear strength of sand and silty sand soils.

\section{DECLARATIONS}

Funding: Not applicable.

Conflicts of interest/Competing interests: The authors declare no conflict of interest/competing interests.

Data availability: Not applicable.

Code availability: Not applicable.

Authors' contributions:

Naveed Khan: Conceptualization, Methodology

Naveed Khan and Muhammad Safdar: Data

curation, Writing- Original draft 
preparation. Muhammad Safdar: Data

interpretation, formatting Irshad Ahmad and

Benish Jehan Khan: Supervision Abdul Qudoos

Khan and Muhammad Safdar: Writing- Reviewing and Editing.

\section{REFERENCES}

[1] P. G. Nicholson, Soil improvement and ground modification methods. ButterworthHeinemann, (2014).

[2] D. H. Gray, and T. Al-Refeai, Behaviour of fabric-versus fibre-reinforced sand. Journal of Geotechnical Engineering 112 (1986) 804820.

[3] D. H. Gray, and H. Ohashi, Mechanics of fibre reinforcement in sand. Journal of Geotechnical Engineering 109 (1983) 335353.

[4] N. C. Consoli, Engineering behaviour of a sand reinforced with plastic waste. Journal of Geotechnical and Geoenvironmental Engineering 128 (2002) 462-472.

[5] P. Wanyama, Experimental study of shear behaviour of high-density polyethylene reinforced sand under triaxial compression, Ph. D. Diss., University of Cape Town, (2017).

[6] S. M. Hejazi, A simple review of soil reinforcement by using natural and synthetic fibres. Construction and building materials 30 (2012) 100-116.

[7] M. H. Maher, and D. H. Gray, Static response of sands reinforced with randomly distributed fibres. Journal of Geotechnical Engineering 116 (1990) 1661-1677.

[8] N. C. Consoli, Shear strength behaviour of fibre-reinforced sand considering triaxial tests under distinct stress paths. Journal of geotechnical and geoenvironmental engineering 133 (2007) 11466-1469.

[9] H. Vidal, The principle of reinforced earth. Highway research record 282 (1969).
[10] C. H. Benson and V. K. Milind, Reinforcing sand with strips of reclaimed high-density polyethylene. Journal of Geotechnical Engineering 120 (1994) 838-855.

[11] J. G. Zornberg, A. R. Cabral and C. Viratjandr, Behaviour of tire shred sand mixtures. Canadian geotechnical journal 41 (2004) 227-241.

[12] F. C. Chebet and D. Kalumba, Laboratory investigation on reusing polyethylene (plastic) bag waste material for soil reinforcement in geotechnical engineering. Civil Engineering and Urban Planning: An International Journal (CiVEJ) 1 (2014) 67-82.

[13] J. J. Claria and P. V. Vettorelo, Mechanical behaviour of loose sand reinforced with synthetic fibres. Soil Mechanics and Foundation Engineering 53 (2016) 12-18.

[14] N. M. Ilieş, Comparative study on soil stabilization with polyethylene waste materials and binders. Procedia Engineering 181 (2017) 444-451.

[15] R. L. Santoni, J. S. Tingle, and S. L. Webster, Engineering properties of sand-fibre mixtures for road construction. Journal of geotechnical and geoenvironmental engineering 127 (2001) 258-268.

[16] J. J. Murray, J. D. Frost and Y. Wang, Behaviour of a sandy silt reinforced with discontinuous recycled fibre inclusions. Transportation research record 1714 (2000) 9-17.

[17] J. G. Zornberg, Discrete framework for limit equilibrium analysis of fibre-reinforced soil. Géotechnique 52 (2002) 593-604.

[18] R. L. Michalowski, and J. Čermák, Triaxial compression of sand reinforced with fibres. Journal of geotechnical and geoenvironmental engineering 129 (2003) 125-136. 
[19] K. S. Heineck, M. R. Coop, and N. C. Consoli, Effect of microreinforcement of soils from very small to large shear strains. Journal of geotechnical and geoenvironmental engineering 131 (2005) 1024-1033.

[20] E. Ibraim, and S. Fourmont, Behaviour of sand reinforced with fibres. Soil stress-strain behaviour: Measurement, modeling and analysis. Springer, Dordrecht (2007) 807-818.

[21] S. Sadek, S. S. Najjar, and F. Freiha, Shear strength of fibre-reinforced sands. Journal of geotechnical and geoenvironmental engineering 136 (2010) 490-499.

[22] H. M. Eldesouky, M. M. Morsy, and M. F. Mansour, Fibre-reinforced sand strength and dilation characteristics. Ain Shams Engineering Journal 7 (2016) 517-526.

[23] C. Li, and J. G. Zornberg, Mobilization of reinforcement forces in fibre-reinforced soil. Journal of geotechnical and geoenvironmental engineering 139 (2013) 107-115.
[24] C. S. Chang, and Z. Y. Yin, Micromechanical modeling for behaviour of silty sand with influence of fine content. International Journal of Solids and Structures 48 (2011) 2655-2667.

[25] ASTM D2487, Standard Practice for Classification of Soils for Engineering Purposes (Unified Soil Classification System), ASTM International, West Conshohocken, PA, (2006).

[26] B. M. Das, Principles of Geotechnical Engineering, 7th Edition, (2002).

[27] ASTM C136, Standard Test Method for Sieve Analysis of Fine and Coarse Aggregates, ASTM International, West Conshohocken, PA, (2006).

[28] ASTM D3080/D3080M, Standard test method for direct shear test of soils under consolidated drained conditions, ASTM International, West Conshohocken, PA, (2011).

Received: 22 Aug. 2021. Revised/Accepted: 30 Sep. 2021. 